\title{
The role of self-efficacy in undertaking health-seeking behaviours by physical education teachers
}

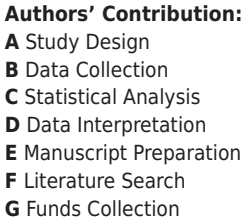

\author{
Zaneta Szczepanska-Klunder ${ }^{1}$ ABCDEFG, Mariusz Lipowski² ACDFG \\ ${ }^{1}$ Middle School no. 17 in Gdynia, Poland \\ 2 Department of Health Psychology, Gdansk University of Physical Education and Sport, \\ Poland
}

\section{abstract}

Background

Material/Methods

Results

Conclusions

Key words
Self-efficacy, defined as a personal resource, is increasingly analysed in context of healthseeking behaviours. Therefore, it is important to explain to what extent these behaviours are associated with cognitive personality disposition of physical education teachers, manifested by their self-efficacy.

We examined 271 physical education teachers $\left(\mathrm{n}_{0}=137\right.$ and $\left.\mathrm{n}_{0^{*}}=134\right)$ aged between 23 and 62 years $(M=38.97, S D=9.33)$. The respondents were surveyed with the Generalized Self-Efficacy Scale by Schwarzer and Jerusalem in the Polish adaptation by Juczynski, Health Behaviour Inventory by Juczynski and the Multidimensional Body-Self Relations Questionnaire by Cash.

Our findings point to a beneficial effect of self-efficacy on Proper Nutrition Habits, Prophylactic Behaviour, Positive Psychological Attitudes and Fitness/Health Orientation. Nevertheless, the use of Indicator Variables in Regression revealed that GSES exerts stronger effect on health-seeking behaviours in men than in women. Furthermore, we did not confirm a crucial role of self-efficacy in undertaking physical activity and Health Practices.

Physical education teachers show moderate levels of health-seeking behaviours; this necessitates stimulating their active involvement in self-promotion of health. This can be achieved by health promotional and educational activities addressed to physical education teachers.

health-seeking behaviours, health psychology, physical education, teachers, physical activity.

\section{article details}

Article statistics

Full-text PDF:

Copyright

Indexation:

Funding:

Conflict of interest: Corresponding author:

Open Access License:
Word count: 4,344; Tables: 3; Figures: 1; References: 63

Received: May 2015; Accepted: June 2015; Published: June 2015

http://www.balticsportscience.com

(c) Gdansk University of Physical Education and Sport, Poland

Celdes, CNKI Scholar (China National Knowledge Infrastructure), CNPIEC, De Gruyter - IBR (International Bibliography of Reviews of Scholarly Literature in the Humanities and Social Sciences), De Gruyter - IBZ (International Bibliography of Periodical Literature in the Humanities and Social Sciences), DOAJ, EBSCO - Central \& Eastern European Academic Source, EBSCO - SPORTDiscus, EBSCO Discovery Service, Google Scholar, Index Copernicus, J-Gate, Naviga (Softweco, Primo Central (ExLibris), ProQuest - Family Health, ProQuest - Health \& Medical Complete, ProQuest - Illustrata: Health Sciences, ProQuest - Nursing \& Allied Health Source, Summon (Serials Solutions/ProQuest, TDOne (TDNet), Ulrich's Periodicals Directory/ulrichsweb, WorldCat (OCLC)

This research received no specific grant from any funding agency in the public, commercial, or not-for-profit sectors.

Authors have declared that no competing interest exists.

Mariusz Lipowski; Department of Health Psychology, Gdansk University of Physical Education and Sport 80-336 Gdańsk, Poland, 1 Kazimierza Gorskiego St.; Phone:+48 (58) 5547 270;

E-mail: mariusz.lipowski@awfis.gda.pl

This is an open access article distributed under the terms of the Creative Commons Attribution-Non-commercial 4.0 International (http://creativecommons.org/licenses/by-nc/4.0/), which permits use, distribution, and reproduction in any medium, provided the original work is properly cited, the use is non-commercial and is otherwise in compliance with the license. 


\section{INTRODUCTION}

Searching for causes of health-seeking behaviours, one should consider not only the behaviours themselves but also the related personality traits and dispositions of an individual [1]. Main personal dispositions associated with one's self-beliefs and expectations constitute predominant determinants of health-oriented activity [2, 3, 4, 5]. Therefore, in order to undertake given health-oriented behaviours, one has to be convinced of having appropriate competencies allowing initiation and execution of a planned activity [6]. Consequently, personality disposition, manifested by self-efficacy, is ascribed an important role in undertaking and maintenance health-oriented attitudes. The sense of self-efficacy refers to one's self-belief of being capable of activities aimed at a chosen objective, despite obstacles and difficulties in its execution $[7,8]$; therefore, self-efficacy can be illustrated by saying 'nothing is impossible to a willing mind'. Consequently, we can achieve the objec-tive of 'being healthy', as the desire of 'health' helps us in finding necessary resources. Moreover, it should be remembered that the sense of self-efficacy can be defined twofold: as an expectation of specific efficacy, manifested as a self-assessment of one's abilities to undertake and continue a given form of action, and as general self-efficacy, being a relatively stable dispositional trait. Usually, expectation of specific efficacy refers to coping with a given situation. In contrast, general self-efficacy reflects one's personal resources, being useful in coping with problems that affect various spheres of life $[9,10,11,12,13]$.

Self-efficacy beliefs constitute main determinants of behavioural choices, amount of efforts, and forces necessary to maintain a given behaviour. This was confirmed by Schwarzer et al. [14], according to whom individuals convinced of their abilities of behavioural control are more likely to transform the intended dietary changes into an established dietary habit. Also Luszczynska, Tryburcy and Schwarzer [15] revealed that the ability to change or maintain healthy nutritional behaviours (despite experienced difficulties) requires a strong sense of self-efficacy. Self-efficacy not only seems to been optimal determinant of changes in nutritional behaviours [16] as confirmed by Scholz et al. [17]; increased self-efficacy is also reflected by favourable changes in other health-seeking behaviours, such as cessation of smoking and implementation of proper dietary habits. Moreover, research proved that self-efficacy plays an important role in controlling body weight, nutritional behaviours, and reduction of overweight $[18,19]$. A vital role of self-efficacy in undertaking and maintaining physical activity should also be mentioned. The sense of self-efficacy was found to be the most coherent psychological correlate of physical activity [20], and it plays a vital role in planning positive changes with regard to physical exercise [21, 22]. It is noteworthy that the sense of self-efficacy is considered the strongest predictor of physical activity, both among adolescents [23] and adults [24], as well as in the elderly [25].

Research proved that general self-efficacy modulates formation of intentions, control of actions and effectiveness of health-related behaviours. Therefore, it can be considered an extremely strong determinant of behaviour; this supports incorporation of this construct into the theory of health-seeking behaviours [26]. 
Obviously, health-seeking behaviours are analysed as determinants of health, and school and Physical Education play a vital role in promotion of the latter [27]. Recently, this role has increasingly been emphasized by many formal guidelines on general education [28], thus obliging Physical Education teachers to enhance health-related attitudes and habits of the youth. Physical education and the person of Physical Education teacher are considered vital for promotion of physical activity among the youth [29, 30]. However, the levels of physical activity presented by children from most countries are lower than recommended [31, 32, 33]. Satisfaction with Physical Education classes may be a determinant of physical activity in school children. Pospiech [34] showed that the fraction of boys and girls from grammar schools who like exercising during Physical Education classes is approximately 50\% lower as compared to primary school pupils. Moreover, the available evidence suggests that pupils who passively repeat the exercises demonstrated by a Physical Education teacher do not fully realize their role as a determinant of health. According to Eather, Morgan and Lubans [35], Physical Education teachers ignore the fact that their inappropriate attitudes presented during Physical Education classes to a large extent can determine their pupils' negative approach to lifetime physical activity. Therefore, the teacher's role should not be limited solely to being an instructor of bodily exercise', but extend to 'a guide to body culture' [36]. Although Physical Education teachers are responsible for determining their pupils' attitudes to sports at school [37], they also undoubtedly play a vital role in the promotion of favourable, health-oriented attitudes $[27,38]$. Physical Education teachers can effectively play this role if they show attitudes promoting physical activity among their pupils [39]. This was confirmed by a study in which social support offered by Physical Education teachers stimulated their pupils' physical activity [35].

In view of the role of Physical Education teachers in promotion of healthy lifestyle, identification of health-seeking behaviours shown by this professional group becomes of particular interest. Nevertheless, our hereby presented research was not limited solely to identification of these behaviours. Since the sense of self-efficacy, defined as a personal resource, is increasingly analysed in the context of health-seeking behaviours, it is important to explain to what extent these behaviours are associated with cognitive personality disposition of Physical Education teachers, manifested by their self-efficacy. As self-efficacy is responsible for motivational and behavioural aspects of humans and regulation of their behaviours, one can assume a positive correlation between the sense of self-efficacy and the prevalence of health-seeking behaviours, namely physical activity, dietary habits, health practices, prophylactic behaviours and a positive psychological attitude of Physical Education teachers. Moreover, referring to theoretical foundations of the self-efficacy construct, that is influence of the variable on a selection of activity intention, one may speculate on a relationship between self-efficacy and activities aimed at improving health and physical condition. Moreover, taking into account the previously reported sex-specific differences with regards to cognitive and social determinants of health behaviours $[40,41]$, we assumed that women and men may differ in terms of the analysed relationships. 


\section{MATERIALS AND METHODS}

\section{Participants and Procedure}

In order to determine the role of self-efficacy in undertaking health-seeking behaviours, we examined a group of Physical Education teachers $(\mathrm{N}=271)$, among them 137 women and 134 men, employed at various types of schools in the Pomeranian Voivodeship. The study group was selected by means of a random purposeful sampling. The operate of sampling was an electronic list of public schools provided by the Superintendent of Schools Office in Gdansk; the schools rather than teachers were sampled. Prior to the study, the authors contacted management of each school informing them on the objectives and logistics of the project. The teachers who gave their consent to participate in the study (it is noteworthy that obtaining teachers' opinions on themselves can be challenging) were asked to complete a set of paper-and-pencil tests. Each test included a comprehensive instruction for the respondent. The participants were assured of the anonymous character of the survey. The results of 12 participants were excluded from analysis since they did not complete all the tests or completed them incorrectly. The participants' age ranged between 23 and 62 years $(M=38.97 ; S D=9.33)$. Duration of employment of the study participants ranged between 1 and 37 years $(M=13.57 ; \mathrm{SD}=9.12)$. A total of $57.56 \%$ of the surveyed Physical Education teachers (\$26.94\%; 030.63\%) were employed at a primary school, and a similar percentage (53.87\%; $925.83 \%$; o'28.04\%) worked at a grammar school. Less than $30 \%$ of the participants (28.78\%; o 15.50\%; o $13.28 \%$ ) were employed at a post-grammar school.

\section{MeAsures}

The sense of self-efficacy was determined with the Generalized Self-Efficacy Scale (GSES) by Schwarzer and Jerusalem [42], in the Polish adaptation by Juczynski [43]. This scale is used to assess optimistic self-beliefs to cope with various difficult situations and obstacles. GSES includes 10 statements representing a single factor. The respondent circles one out of the four answers. The sum of individual scores represents the global self-efficacy score, which can be interpreted using the sten scale. The higher the score, the higher one's self-efficacy level. The global score can be also standardized. The reliability of the scale determined with a test-retest method amounted to 0.78 and therefore was similar to the reliability of the original instrument. The level of health-seeking behaviours was measured with the Health Behaviour Inventory (HBI) by Juczynski [43], which includes 24 statements regarding various types of health-related behaviours. Based on the self-reported frequency of undertaking various behaviours, global health-seeking behaviour score is determined along with its four components: Proper Nutrition Habits, Prophylactic Behaviour, Health Practices, and Positive Psychological Attitudes. The global health-seeking behaviour score can range between 24 and 120 points. The higher the score, the greater the intensity of specific health-oriented behaviours. The global score can be also presented on the sten scale in order to facilitate its interpretation. The internal consistency rate of the scale expressed by Cronbach's alpha is 0.85 for the whole inventory and 0.60-0.65 for its subscales. The test-retest correlation coefficient of the scale is 0.88 . Satisfactory accuracy of the scale was also confirmed on the basis of factorial analysis and strong correlations between its scores and the results of other 
tests determining the level of health behaviours. Moreover, other characteristics of the participants, such as their gender, age, duration of employment as a teacher, weekly amount of time spent on physical activity, and forms of physical activity practiced on a recreational basis were determined with an aid of a questionnaire survey.

Self-reported levels of health and physical condition were determined with the Multidimensional Body-Self Relations Questionnaire MBSRQ [44]. The scale includes 69 questions divided into nine subscales. Two of these subscales, Fitness/Health Evaluation and Fitness/Health Orientation, were analysed in the present study. The Evaluation score reflects self-attitude (positive or negative) to one's image, health and physical condition, while the Orientation score shows if the respondent undertakes activities aimed at improving his/her image, health or physical condition. Each subscale can be scored as: extremely low, low, moderate, high or extremely high. The respondent decides to which degree the statements included in a given subscale refer to his/her image, health and physical condition, scoring them from 1 (I completely disagree) to 5 (I absolutely agree). The final scores are calculated separately for each subscale, as the sum of scores for individual statements; some scores need to be inversed prior to the calculation.

\section{Statistical Analysis}

Statistical analysis was conducted with Statistica 10 software: Student's t-test, General Linear Models, r-Pearson correlation, Multiple Regression and Indicator Variables in Regression.

\section{RESULTS}

Firstly, statistical analysis of self-efficacy levels was conducted. Our participants turned out to be characterized by a strong sense of self-efficacy (sten values: $\mathrm{M}=7.28$; $\mathrm{SD}=1.51$ ). Comparative analysis did not reveal significant gender-related differences in the mean values of the self-efficacy scale (Table 1 ). The overall score of health-seeking behaviours (sten values: $M=5.70$; $\mathrm{SD}=1.70$ ) among Physical Education teachers corresponded to a moderate level of this variable. Similarly, moderate values of all four individual categories of health-seeking behaviours were recorded. However, the comparative analysis of gender-related differences (Table 1) revealed that the values of General Intensity of Health Behaviour, Proper Nutrition Habits, Prophylactic Behaviour and Positive Psychological Attitudes were higher in women than in men.

Moreover, the comparative analysis showed (Table 1) that female and male participants did not differ significantly in terms of age and duration of employment as a Physical Education teacher. Furthermore, men and women were characterized by similar levels of self-reported health and physical condition.

However, it is noteworthy that the self-reported levels of physical condition and health among women differed depending on self-efficacy levels: namely, women presenting a moderate sense of self-efficacy scored lower on the Fitness/Health Evaluation scale $(t=2.80 ; \mathrm{p}=.006)$. A similar phe-nomenon was observed for the Fitness/Health Orientation scale $(t=2.15 ; p=.032)$. In the case of men, the sense of self-efficacy turned out to modulate solely the self- 
-reported level of physical con-dition and health: males showing a moderate sense of self-efficacy achieved lower scores on the Fitness/Health Evaluation scale $(\mathrm{t}=3.14 ; \mathrm{p}=.002)$.

Table 1. Mean levels of General Self-Efficacy, Health-Seeking Behaviours, MBSRQ scores, age and duration of employment in the studied group of Physical Education teachers

\begin{tabular}{cccc} 
& Women & Men & Difference \\
Parameter & M (SD) & M (SD) & $\mathrm{t}(\mathrm{p})$ \\
\hline Age & $39.45(8.70)$ & $38.49(9.94)$ & $0.85(.396)$ \\
\hline Duration of employment & $14.19(8.91)$ & $12.94(9.34)$ & $1.12(.262)$ \\
\hline Generalized Self-Efficacy & $31.52(4.36)$ & $31.90(4.16)$ & $0.73(.467)$ \\
\hline Health Behaviour Inventory: & & & \\
\hline Proper nutrition habits & $22.03(3.87)$ & $20.00(4.43)$ & $4.03(.000)$ \\
\hline Prophylactic behaviour & $21.35(3.75)$ & $19.81(4.35)$ & $3.14(.002)$ \\
\hline Positive psychological attitudes & $22.34(3.35)$ & $21.40(3.77)$ & $2.17(.031)$ \\
\hline Health practices & $20.11(3.74)$ & $19.24(3.79)$ & $1.90(.058)$ \\
\hline General intensity of health behaviour & $85.82(11.32)$ & $80.43(13.18)$ & $3.61(.000)$ \\
\hline MBSRQ: & & & \\
\hline Fitness/Health Evaluation & $42.44(5.46)$ & $42.83(5.62)$ & $0.58(.564)$ \\
\hline Fitness/Health Orientation & $51.12(6.00)$ & $50.41(5.28)$ & $1.03(.303)$ \\
\hline
\end{tabular}

The analysis of physical activity-related variables revealed that the majority of both female (16.78\%) and male respondents (15.67\%)spent two hours weekly on recreational physical activity and involved in only its one form $(\mathrm{M}=1.25$; $\mathrm{SD}=0.77)$. The comparative analysis of gender-related differences showed that the amount of time spent on physical activity by women was lower than that of men $(\mathrm{M}$ female $=4.31$; $\mathrm{SD}$ female $=3.05 ; \mathrm{M}$ male $=5.43 ; \mathrm{SD}$ male $=$ 4.87; $\mathrm{p}=.025$ ). In turn, male and female participants did not differ significantly in the number of forms of physical activity practiced on a recreational basis.

As expected, women chose different forms of recreational physical activity than men (Table 2). Contrary to men, women preferred aerobics, and males more often involved in weightlifting exercises. Apart from these two disciplines, both women and men declared practicing swimming, jogging and volleyball. Although women declared involvement in these forms of physical activity more often than men, the gender-related differences did not prove significant in statistical analysis.

Table 2. Distributions of physical activity (PA) forms preferred by female and male teachers of Physical Education

\begin{tabular}{cccc}
\hline Form of PA & Women & Men & $\mathrm{p}$ \\
\hline Aerobics & $24.82 \%$ & $0.75 \%$ & .000 \\
\hline Weightlifting & $3.65 \%$ & $17.91 \%$ & .000 \\
\hline Swimming & $23.36 \%$ & $17.16 \%$ & .206 \\
\hline Jogging & $21.90 \%$ & $18.66 \%$ & .508 \\
\hline Volleyball & $18.90 \%$ & $14.93 \%$ & .376 \\
\hline
\end{tabular}

In order to verify which of the independent variables (self-efficacy, age, duration of employment, Fitness/Health Evaluation) exerted the strongest effect 
on the dependent variables (Proper Nutrition Habits, Prophylactic Behaviour, Positive Psychological Attitudes, Health Practices, weekly amount of time spent on physical activity, number of recreational physical activity forms, and Fitness/Health Orientation), we conducted a series of multiple regression analyses. As women and men turned out to differ in terms of both independent and dependent variables, the regression analyses were conducted separately for each gender. All models of regression that reached statistical significance are shown in Figure 1; only the models with a weekly amount of time spent on physical activity and a number of recreational physical activity forms as dependent variables were not presented graphically as they did not reach the predefined threshold of statistical significance $(p<.05)$. The effects of independent variables documented in individual regression models seemed to be markedly stronger in men than in women, as suggested by nearly twice as high number of statistically significant $\beta$ coefficients (Figure 1).

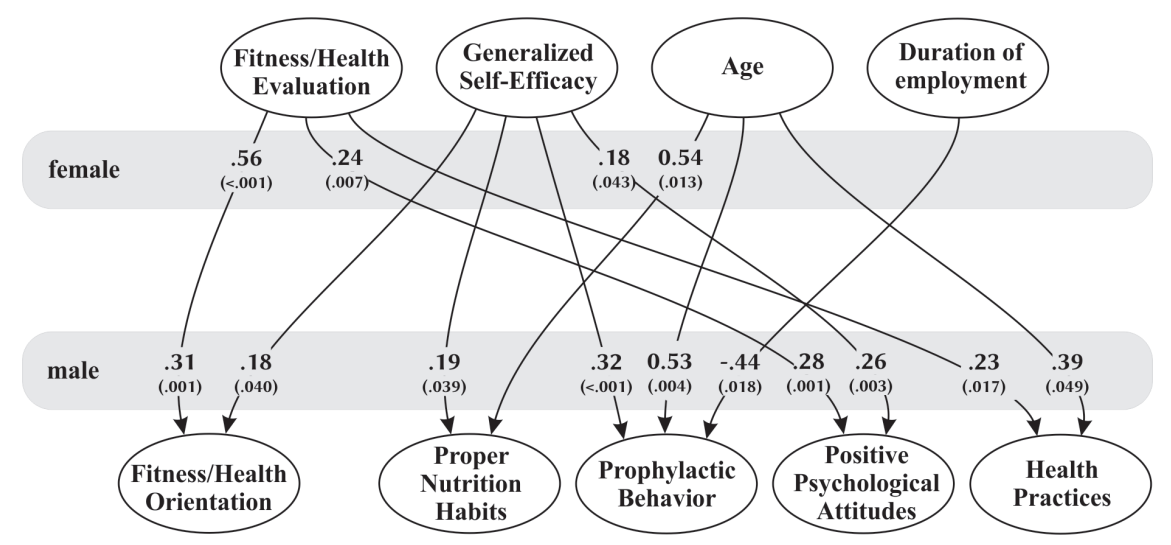

Fig 1. The effects of independent variables documented in individual regression models

In the case of women, the most optimally fitted model of regression (explaining $37.32 \%$ of variance, $F=19.50, p=.000$ ) was observed for the effect of Fitness/Health Orientation on Fit-ness/Health Evaluation. In contrast, in men the regression explained only $18.32 \%$ of variance in this dependent variable. It is noteworthy that the effect of Fitness/Health Orientation on Fitness/Health Evaluation in women and men was different, as confirmed with the use of Indicator Variables in Regression. The effect of Fitness/Health Orientation turned out to be stronger in the case of women (dummy variable: $t=2.81, p=.005$ ).

Irrespective of gender, the analysis of Positive Psychological Attitudes as a dependent variable produced similar models of regression; the regression explained $12.50 \%(\mathrm{~F}=4.68, \mathrm{p}=.002)$ and $21.11 \%(\mathrm{~F}=8.43, \mathrm{p}=.000)$ of variance in women and men, respectively. Furthermore, the use of Indicator Variables in Regression did not reveal significant differences between $\beta$ coefficients of female and male respondents.

In the case of male teachers, an interesting model was obtained for Prophylactic Behaviour as a dependent variable; the regression explained $19.58 \%$ of variance in this variable $(F=7.67, p=.000)$. In contrast, the analogous model did not reach the predefined threshold of statistical significance in women. The analysis with Indicator Variables in Regression confirmed that the effect of GSES as an independent variable was stronger in men than in women (dummy variable: $\mathrm{t}=1.99, \mathrm{p}=.048$ ). 
The coefficients of correlation between general self-efficacy determined with GSES scale and health-seeking behaviours documented using HBI are presented in Table 3. The data presented in the table suggest that involvement in health-oriented practices increases proportionally to the sense of self-efficacy, as confirmed by the positive correlations between this parameter and Prophylactic Behaviour and Positive Psychological Attitudes scores. In contrast, the analysis of correlation did not confirm our assumption on the significant role of self-efficacy in undertaking physical activity and Health Practices.

Table 3. Correlations between GSES, HBI and MBSRQ scores in the studied group of Physical Education teachers

\begin{tabular}{|c|c|c|c|c|c|c|c|c|c|}
\hline \multirow{2}{*}{$\begin{array}{c}\text { Scale } \\
\text { Physical } \\
\text { activity: }\end{array}$} & \multirow[t]{2}{*}{ Sex } & \multicolumn{2}{|c|}{ GSES } & \multicolumn{2}{|c|}{$\begin{array}{l}\text { Fitness/Health } \\
\text { Evaluation }\end{array}$} & \multicolumn{2}{|c|}{ Age } & \multicolumn{2}{|c|}{$\begin{array}{l}\text { Duration } \\
\text { of employment }\end{array}$} \\
\hline & & & & & & & & & \\
\hline \multirow{2}{*}{$\begin{array}{l}\text { Number of } \\
\text { hours }\end{array}$} & f & -.03 & & .15 & & -.15 & & -.15 & \\
\hline & $\mathrm{m}$ & .08 & & .16 & & -.21 & $(.015)$ & -.18 & $(.043)$ \\
\hline \multirow{2}{*}{$\begin{array}{l}\text { Number of } \\
\text { forms }\end{array}$} & $f$ & .00 & & .02 & & .14 & & .11 & \\
\hline & $\mathrm{m}$ & .04 & & .12 & & .06 & & .01 & \\
\hline \multicolumn{10}{|l|}{$\mathrm{HBI}:$} \\
\hline \multirow{2}{*}{$\begin{array}{l}\text { Proper } \\
\text { Nutrition } \\
\text { Habits }\end{array}$} & $f$ & .11 & & .12 & & .17 & $(.050)$ & .09 & \\
\hline & $\mathrm{m}$ & .23 & $(.008)$ & .15 & & .06 & & .01 & \\
\hline \multirow{2}{*}{$\begin{array}{l}\text { Prophylac- } \\
\text { tic Beha- } \\
\text { viour }\end{array}$} & $f$ & .19 & $(.031)$ & .17 & & .22 & $(.011)$ & .17 & $(.044)$ \\
\hline & $\mathrm{m}$ & .36 & $(.000)$ & .22 & $(.012)$ & .12 & & .03 & \\
\hline \multirow{2}{*}{$\begin{array}{l}\text { Positive } \\
\text { Psychologi- } \\
\text { cal Attitu- } \\
\text { des }\end{array}$} & $f$ & .25 & $(.004)$ & .28 & $(.001)$ & .08 & & .05 & \\
\hline & $\mathrm{m}$ & .36 & $(.000)$ & .36 & $(.000)$ & .10 & & .08 & \\
\hline \multirow{2}{*}{$\begin{array}{l}\text { Health } \\
\text { Practices }\end{array}$} & f & .08 & & .12 & & .04 & & .01 & \\
\hline & $\mathrm{m}$ & .12 & & .22 & $(.013)$ & .09 & & .03 & \\
\hline \multicolumn{10}{|l|}{ MBSRQ: } \\
\hline \multirow{2}{*}{$\begin{array}{l}\text { Fitness/ } \\
\text { Health }\end{array}$} & f & .27 & $(.001)$ & .60 & $(.000)$ & .10 & & .08 & \\
\hline & $\mathrm{m}$ & .30 & $(.001)$ & .36 & $(.000)$ & .01 & & -.04 & \\
\hline
\end{tabular}

Note: $r(p) ; f$ - female, $m$ - male

The correlation between Fitness/Health Orientation and self-efficacy (Table 3) was observed in both women and men. Therefore, a stronger sense of self-efficacy seemed to be associated with a greater involvement in activities aimed at improving health and the physical condition. Furthermore, we observed that these were men not women who spent more time on physical activity aimed at improving their health and physical condition $(\mathrm{p}=.005)$.

\section{DISCUSSION}

Personality-related factors seem to play an important role in undertaking and maintaining health-related behaviours [45, 46, 47]. A growing number of studies confirmed the role of self-efficacy in this process [48, 49]. Our study revealed that individuals showing a stronger sense of self-efficacy are characterized by a healthier lifestyle, as confirmed by higher scores of Prophylactic Behaviour and Positive Psychological Attitudes. It is noteworthy that this as- 
sociation turned out to be stronger in men than in women. This phenomenon was confirmed by the multiple regression anal-ysis, which showed that self-efficacy influences 3 out of 4 categories of health-seeking behaviours analysed in men. This is consistent with the data suggesting that efficient decision making and self-efficacy represent characteristics of a masculine stereotype, thus being associated with a self-agency dimension. In contrast, interpersonal skills are associated with a feminine stereotype, which incorporates commonality-specific traits [50]. Therefore, a more evident role of self-efficacy in health-seeking behaviours undertaken by men can be associated with orientation on success, and stronger self-efficacy not only enables undertaking such behaviours but also their improvement [6]. However, our observations of a higher level of health-seeking behaviours among women than among men are consistent with the results of previous studies dealing with the problem in question $[41,51,52]$.

Self-efficacy seems to be the best independent prognostic factor for various health-seeking behaviours [22, 53]. According to Schwarzer et al. [14], without the sense of self-efficacy, any intentions to improve health-seeking behaviours are not reflected by efficient planning of one's activities. In view of the results of previous studies, the hereby documented association between General Self-Efficacy and Fitness/Health Orientation suggests that Physical Education teachers involve in health-oriented activities, as they believe that investment of energetic resources will be eventually reflected by the expected improvement in their health and physical condition. It is noteworthy that Physical Education teachers differ from the general population in terms of their lifestyle characteristics. According to Sandmark [54], Physical Education teachers are more involved in lifetime physical activity and show lower body mass indices than the general population. Also Pihl, Matsin and Jürimäe [55] suggested that greater involvement of Physical Education teachers in physical activity results in a lower risk of overweight, hypertension and musculoskeletal disorders than in teachers representing other specialties.

The result of our multiple regression analysis, suggesting that the effect of self-efficacy on dependent variables is stronger in men than in women, is worth emphasizing. Although participants of both genders showed similar levels of self-efficacy, we expected that women will be characterized by a healthier lifestyle than men [56]. On the one hand, the result of our regression analysis is consistent with the assumption on the important role of self-efficacy in undertaking health-seeking behaviours $[6,26]$. On the other hand, our findings point to a necessity of a more thorough analysis [57] that could identify potential gender-related differences in the psychological processes underlying health-seeking behaviours [41]. Self-efficacy is not a universal determinant of health-seeking behaviours in both genders, as the latter seem to be determined also by gender roles or other im-portant factors, such as socioeconomic or cultural characteristics [58].

Comparing our findings with the results published by other researchers, one may note that according to many authors, a high level of self-efficacy can be a prerequisite for undertaking and maintaining physical activity [53, 59]. Although a number of researchers confirmed the predictive role of self-efficacy in undertaking physical activity $[23,24,60]$, we did not find such an association in our study. This may reflect the complexity of health-seeking behaviour 
determinants, or be inherent to the study protocol. Our findings may reflect the fact of using separate instruments for determining the sense of self-efficacy and the level of physical activity. Another limitation of the hereby presented analysis can be incomparability of its findings with the results of previous research, resulting from different age structure of our participants. As emphasized by Higgins et al. [60] on the basis of a meta-analysis of various studies, enhancement of behaviours related to physical exercise is associated with stronger self-efficacy, but only if interventions aimed at promotion of physical activity include self-efficacy promoting techniques. Discrepancies between the results of many studies aimed at increasing physical activity and strengthening self-efficacy can be explained by a different character of implemented interventions; some of them might hinder the development of general self-efficacy or self-efficacy related to physical exercise [60]. Nevertheless, it should be emphasized that the lack of confirmatory answer to our research question on an association between the sense of self-efficacy and physical activity results from a complex and multifactorial character of health-seeking behaviours, rather than from a weakness of this construct.

In turn, the evidence of positive associations between Fitness/Health Orientation, Proper Nutrition Habits, Prophylactic Behaviour and Positive Psychological Attitudes can be interpreted in terms of knowledge of the determinants of health-seeking behaviours. On the other hand, it can reflect the teachers' role in the process of physical education. Undoubtedly, introducing their pupils to a world of health culture, Physical Education teachers themselves should be actively involved in these sphere, thus creating a pattern of positive, health-oriented attitudes [54, 55].

Our study revealed an unsatisfactory level of weekly physical activity among our participants. This is consistent with the results of previous studies on health-oriented activities of Physical Education teachers [61]. However, these findings should be interpreted with care as our study included a group of persons who involve in physical activity on a daily basis. Furthermore, we revealed that these are men not women who more proactively involve in physical activity aimed at improving physical condition and health. Supposedly, this can be associated with the intensity of prophylactic behaviours which, as suggested by the results of multiple regression analysis, increases proportionally to age and duration of employment as a Physical Education teacher. Therefore, it can be assumed that the older the Physical Education teacher, the greater his/her involvement in physical activity aimed at improving health or physical condition. Moreover, it should be remembered that in the process of physical education, body is perceived not only from a health perspective but also in the context of proper physical skills [62]. Therefore, in order to efficiently conduct the process of physical education, the teachers should not only present health-oriented attitudes, but also pro-somatic approaches associated with physical condition, of sufficient intensity to not transmit a distorted behavioural pattern [63].

In conclusion, the results of this study partially confirmed our initial assumptions. The lack of the confirmatory answer to the question on an association between the sense of self-efficacy and physical activity can be interpreted in terms of complexity of the analysed variables, which necessitates adjustment for a number of covariates, e.g. the sense of coherence, health locus of con- 
trol, satisfaction with life, optimism or valuation of health. Nevertheless, our findings partially confirmed the important role of self-efficacy in undertaking Proper Nutrition Habits, Prophylactic Behaviour, Positive Psychological Attitudes and Fitness/Health Orientation. This result is consistent with our initial assumption according to which involvement in health-seeking activities, striving for improvement and maintenance of health and physical condition are associated with stronger self-efficacy.

\section{CONCLUSION}

Although our findings point to a beneficial effect of self-efficacy on prophylactic behaviours and a positive psychological attitude. We did not confirm the crucial role of self-efficacy in undertaking physical activity and health-oriented practices. Techniques strengthening the sense of self-efficacy in Physical Education teachers can prove valuable in this context.

Both women and men show moderate levels of health-seeking behaviours; this necessitates stimulating their active involvement in self-promotion of health. This can be achieved by health promotional and educational activities addressed to Physical Education teachers. The changes implemented into the educational process of Physical Education teachers can prove valuable in this context.

\section{REFERENCES}

[1] Bishop GD. Psychologia zdrowia [Psychology of Health]. Wroclaw: Astrum; 2000. Polish.

[2] Ebstrup JF, Aadahl M, Eplov FL, Pisinger C, Jørgensen T. Cross-sectional associations between the Five Factor personality traits and leisure-time sitting-time: the effect of general self-efficacy. J Phys Act Health. 2013;10(4): 572-580.

[3] Jones F, Harris P, Waller H, Coggins A. Adherence to an exercise prescription scheme: The role of expectations, self-efficacy, stage of change and psychological well-being. Br J Health Psychol. 2005;10(3):359-378.

[4] Ochsner S, Scholz U, Hornung R. Testing phase-specific self-efficacy beliefs in the context of dietary behaviour change. Applied Psychology: Health and Well-Being. 2013;5(1):99-117.

[5] Sniehotta FF, Scholz U, Schwarzer R. Bridging the intention-behaviour gap: Planning, self-efficacy, and action control in the adoption and maintenance of physical exercise. PsycholHealth. 2005;20(2):143-160.

[6] Bandura A. Self-efficacy: The exercise of control. New York: Freeman; 1997.

[7] Bandura A. Social cognitive theory: an agentic perspective. Annu Rev Psychol. 2001;52:1-26.

[8] Bandura A. Teoria spolecznego uczenia sie [Theory of Social Learning]. Warszawa: PWN; 2007. Polish.

[9] Ebstrup JF, Eplov FL, Pisinger C, Jørgensen T. Association between the Five Factor personality traits and perceived stress: is the effect mediated by general self-efficacy? Anxiety Stress Coping. 2011;24 (4):407-419.

[10] Klassen R, Wilson E, Siu AFY, et al. Preservice teachers' work stress, self-efficacy, and occupational commitment in four countries. Eur J Psychol Educ. 2013;28(4):1289-1309.

[11] Paxton RJ, Molt RW, Aylward A, Nigg CR. Physical activity and quality of life - the complementary influence of self-efficacy for physical activity and mental health difficulties. Int J Behav Med. 2010;17(4):255-263.

[12] Scholz U, Sniehotta FF, Schwarzer R. Predicting physical exercise in cardiac rehabilitation: the role of phase-specific self-efficacy beliefs. J Sport Exerc Psychol. 2005;27:135-151.

[13] Canrinus ET, Helms-Lorenz M, Beijaard D, Buitink J, Hofman A. Self-efficacy, job satisfaction, motivation and commitment: exploring the relationships between indicators of teachers' professional identity. Eur J Psychol Educ. 2012;27(1):115-132.

[14] Schwarzer R, Richert J, Kreausukon P, RemmeL, Wiedemann A, Reuter T. Translating intentions into nutrition behaviours via planning requires self-efficacy: Evidence from Thailand and Germany. Int J Psychol. 2010;45(4):260-268.

[15] Luszczynska A, Tryburcy M, Schwarzer, R. Improving fruit and vegetable consumption: A self-efficacy intervention compared to a combined self-efficacy and planning intervention. Health Educ Res. 2007;22(5):630638.

[16] Kreausukon P, Gellert P, Lippke S, Schwarzer R. Planning and self-efficacy can increase fruit and vegetable consumption: a randomized controlled trial. J Behav Med. 2012;35(4):443-451.

[17] Scholz U, Nagy G, Goehner W, Luszczyńska A, Kliegel M. Changes in self-regulatory cognitions as predictors of changes in smoking and nutrition behaviour. Psychol Health. 2009;24(5):545-561. 
[18] Benyamini Y, Geron R, Steinberg D, Medini N, Valinsky L, Endevelt R. A structured intentions and action-planning intervention improves weight loss outcomes in group weight loss program. Am J Health Promot. 2013;28(2):119-127.

[19] Oginska-Bulik N. Psychologia nadmiernego jedzenia. Przyczyny - Konsekwencje - Sposoby zmiany [Psychology of Excessive Eating. Causes - Consequences - Ways of Changing]. Lodz: UL; 2004. Polish.

[20] Kaewthummanukul T, Brown KC. Determinants of employee participation in physical activity: critical review of the literature. AAOHN J. 2006;54(6):249-261.

[21] Burke V, Beilin LJ, Cutt HE, Mansour J, Mori TA. Moderators and mediators of behaviour change in a lifestyle program for treated hypertensives: A randomized controlled trial (ADAPT). Health Educ Res. 2008;23(4):583-591.

[22] Luszczynska A, Schwarzer R, Lippke S, Mazurkiewicz M. Self-efficacy as a moderator of the planning-behaviour relationship in interventions designed to promote physical activity. Psychol Health. 2011;26(2):151166.

[23] Spence JC, Blanchard CM, Clark M, Plotnikoff RC, Storey KE, McCargar L. The role of self-efficacy in explaining gender differences in physical activity among adolescents: a multilevel analysis. J Phys Act Health. 2010;7(2):176-183.

[24] Jeffrey P. Physical activity behaviours, motivation and self-efficacy among college students. Coll Stud J. 2013;47(1):64-74.

[25] Orsega-Smith E, Payne L, Mowen A, Ching-Hua H, Godbey G. Role of social support and self-efficacy in shaping the leisure time physical activity of older adults. J Leis Res. 2007;39(4):705-727.

[26] Schwarzer R. Poczucie wlasnej skutecznosci w podejmowaniu i kontynowaniu zachowan zdrowotnych. Dotychczasowe podejscie teoretyczne i nowy model [Self-efficacy in undertaking and continuation of health-seeking behaviours. Previous theoretical approach and a new model]. In: Heszen-Niejodek I, Sek H, editors. Psychologia zdrowia [Psychology of Health]. Warszawa: PWN; 1997, 157-205. Polish.

[27] Cale L, Harris J. ,Every child (of every size) matters' in physical education! Physical education's role in childhood obesity. Sport Educ Soc.2013;18(4):433-453.

[28] Rozporzadzenie Ministra Edukacji Narodowej z dnia 23 grudnia 2008 roku w sprawie podstawy programowej wychowania przedszkolnego oraz ksztalcenia ogolnego w poszczegolnych typach szkol [Decree of the Minister of National Education of 23 December 2008 on Curriculum Foundations of Preschool and General Education in Various Types of Schools]. Journal of Law of the Re-public of Poland;4: 17. Polish.

[29] Cale L, Harris J. School-based physical activity interventions: effectiveness, trends, issues, implications and recommendations for practice. Sport Educ Soc. 2006;11 (4):401-421.

[30] Niven A, Henretty J, FawknerS. 'It's too crowded': A qualitative study of the physical environment factors that adolescent girls perceive to be important and influential on their PE experience. Euro-Phys Educ Rev. 2014;20:335-348.

[31] Elgar FJ, Pförtner T, Moor I, De Clercq B, Stevens GM, Currie C. Socioeconomic inequalities in adolescent health 2002-2010: a time-series analysis of 34 countries participating in the Health Be-haviour in School-aged Children study. Lancet. 2015;385(9982):2088-2095 .

[32] François T. Tracking of Physical Activity from Childhood to Adulthood. Med Sci Sports Exerc. 2004;36(11):1937-1943.

[33] World Health Organization. Global Recommendations on Physical Activity for Health. Genewa: WHO, 2010.

[34] Pospiech J. Jakosc europejskiego wychowania fizycznego w swietle badan [Quality of European physical education system in view of research findings]. Raciborz: Panstwowa Wyzsza Szkola Zawodowa; 2006. Polish.

[35] Eather N, Morgan P, Lubans D. Social support from teachers mediates physical activity behaviour change in children participating in the Fit-4-Fun intervention. Int J Behav Nutr Phys Act. 2013;10(1):68-84.

[36] Pawlucki A. Pedagogika wartosci ciala [Pedagogy of body value]. Gdansk: AWF, 1996. Polish.

[37] Bowles R, O’Sullivan M. Rhetoric and reality: the role of the teacher in shaping a school sport programme. PhysEduc Sport Pedagog. 2012;17(3):303-317.

[38] Green K. Mission impossible? Reflecting upon the relationship between physical education, youth sport and lifelong participation. Sport Educ Soc. 2014;19(4):357-375.

[39] Patterson D, van der Mars H. Distant interactions and their effects on children's physical activity levels. Phys Educ Sport Pedagog. 2008;13(3):277-294.

[40] Asci F, Lindwall M, Altintas A, Edepli Gursel N. Gender differences in the relation of personality traits and self-presentation with physical activity. Sci Sports. 2015; 30(1):23-30.

[41] Hankonen N, Absetz P, Ghisletta P, Renner B, Uutela A. Gender differences in social cognitive determinants of exercise adoption. Psychol Health. 2010;25(1):55-69.

[42] Schwarzer R, Jerusalem M. Generalized Self-Efficacy Scale. In: Weinman J, Wright S, Johnston M, editors. Measures in Health Psychology: A User's Portfolio. Causal and Control Beliefs. England: Nfer-Nelson; 1995, 35-37.

[43] Juczynski Z. Narzedzia pomiaru w promocji i psychologii zdrowia [Instruments for Measurement in Health Promotion and Psychology]. Warszawa: PTP; 2001.

[44] Cash TF. Users' manual for the Multidimensional Body Self Relations Questionnaire (3rd revision), 2000. http://www.body-images.com/.

[45] Lipowski M, Bieleninik L. Personality superfactors and healthy behaviours of professional athletes. Current Issues in Personality Psychology. 2014;2(2);57-67.

[46] Renner B, Hankonen N, Ghisletta P, Absetz P. Dynamic psychological and behavioural changes in the adoption and maintenance of exercise. Health Psychol. 2012;31(3):306-315. 
[47] Szczepanska-Klunder Z, Lipowski M. Sense of coherence as a moderator of health-related behaviour of physical education teachers. Balt J Health Phys Act. 2014;6(2):127-134.

[48] Abu Sabha R, Achterberg C. Review of self-efficacy and locus of control for nutrition- and health-related behaviour. J Am Diet Assoc. 1997;97(10):1122-1132.

[49] Schwarzer R, Schuez, B, Ziegelmann J, Lippke S, Luszczynska A, Scholz U. Adoption and maintenance of four health behaviours: theory-guided longitudinal studies on dental flossing, seat belt use, dietary behaviour and physical activity. Ann Behav Med. 2007;33(2):165-166.

[50] Wojciszke B. Sprawczosc i wspolnotowosc. Podstawowe wymiary spostrzegania spolecznego [Self-agency and Commonality. Basic Dimensions of Social Perception]. Sopot: GWP; 2010. Polish.

[51] Lipowski M, Bulinski L, Krawczynski M. Physical activities among other types of health-related behaviour in people losing weight. Med Sci Monit. 2009;15(8):423-428.

[52] Wang WC, Worsley A, Hunter W. Similar but different. Health behaviour pathways differ between men and women. Appetite. 2012;58(2):760-766.

[53] Fleig L, Pomp S, Parschau L, Barz M, Lange D, Schwarzer R, Lippke S. From intentions via planning and behaviour to physical exercise habits. Psychol Sport Exerc. 2013;14(5):632-639.

[54] Sandmark H. Musculoskeletal dysfunction in physical education teachers. Occup Environ Med. 2000;57(10):673-677.

[55] Pihl E, Matsin T, Jürimäe T. Physical activity, musculoskeletal disorders and cardiovascular risk factors in male physical education teachers. J Sports Med Phys Fitness. 2002;42(4):466-471.

[56] Barford A, Dorling D, Smith GD, Shaw M. Life expectancy: women now on top everywhere. Br Med J. 2006;332(7545):808.

[57] Anon. Exploring Concepts of Gender and Health. [Available at http://www.hc-sc.gc.ca/hl- vs/pubs/women-femmes/index-eng.php/] [Accessed on 6 January, 2014].

[58] Duetz MS, Abel T, Niemann S. Health measures: differentiating associations with gender and socio-economic status. Eur J Pub Health. 2003;13(4):313-322.

[59] Parschau L, Fleig L, Koring M, Lange D, Knoll N, Schwarzer R, Lippke S. Positive experience, self-efficacy, and action control predict physical activity changes: A moderated mediation analysis. Br J Health Psychol. 2013;18(2):395-406.

[60] Higgins TJ, Middleton KR, Winner L, Janelle CM. Physical activity interventions differentially affect exercise task and barrier self-efficacy: a meta-analysis. Health Psychol. 2013;33(8):891-903.

[61] Lipowski M, Szczepanska-Klunder Z. Zachowania zdrowotne nauczycieli wychowania fizycznego [Health-seeking behaviours of physical education teachers]. In: Jastrzębski Z, editor. Teoria wychowania fizycznego i sportu [Theory of Physical Education and Sport]. Łódź: WSS; 2012, 9-26. Polish.

[62] Webb L, Quennerstedt M, Ohman M. Healthy bodies: construction of the body and health physical education. Sport Edu Soc. 2008;13(4):353-372.

[63] Macik D, Kowalska-Dabrowska K. The risk of muscle dysmorphia and the perception of change in retrospective, current and ideal self-image - preliminary study. Health Psychol Rep. 2015;3(1). DOI: 10.5114/ hpr.2015.47087. 